\title{
The Impact of Authorized Representatives on Energy Efficiency in Multifamily Apartment Houses and Prolongation of the Lifetime of the Buildings
}

\author{
Aleksandra Cimbale ${ }^{1}$, \\ ${ }^{1}$ Ltd. ,Rīgas namu pārvaldnieks”
}

\begin{abstract}
It has been determined that apartments are the most common type of immovable property owned by the inhabitants of Latvia. The detailed analysis of the housing stock of the country shows that the lifetimes of numerous residential buildings are overestimated and only proper administration and maintenance might prolong the terms. The election of authorized or delegated representatives in intercommunities definitely leads to the increase of energy efficiency of the house and ensures proper management of other everyday occasions.
\end{abstract}

Keywords - Energy efficiency, immovable property, intercommunity, residential house

\section{INTRODUCTION}

Apartments are the most common type of immovable property owned by the inhabitants of Latvia and offered on the property market. Closer observation of the housing stock of the country in general, especially in densely populated areas, for example such as the city of Riga, justify the necessity of constant improvements in the form of service and refurbishments with the aim to maintain the current conditions, to perform improvements and prolong the lifetime of every building. Delegated representatives authorized by intercommunities are an additional instrument in the hands of the apartment owners, maintenance companies and municipalities.

The housing stock of the country is formed by different types of immovable property that can be classified in accordance with the ownership status, age (construction period), size (amount of apartments and area), repetition of projects or chosen construction materials. There is no universal recipe for a minor group of buildings, but the special approach cannot be ensured due to the limited abilities of the servicing company. Existing limitations are mostly created by the local legislative acts and norms, especially in the field of ownership and making of common decisions. A delegated representative, chosen and trusted, or associations, formed by the most owners of the apartments in the residential building, yet accepted by the servicing company, can become not only an additional source of information and initiative, but mostly an organ comparable to the heart following constantly and simultaneously the conditions of the house and providing the required signals to the rest of the body. Such persons instantly react at the changes in the building, provide regular and trusted feedback, and ensure a stable and reliable flow of information.

Among other, authorized representatives are capable to accumulate (trough studies, seminars, experience exchange with colleagues, etc.) and provide sufficient information on the conditions of energy audit, renovation and financing of such projects to the intercommunity. Having the required will and knowledge, he or she is the person to follow the process and provide the necessary support till the successful finish of the works.

\section{THE LEGISLATIVE BASIS OF OWNERSHIP AND MAINTENANCE}

There are several important laws describing the situation and possible actions considering ownership of apartments, intercommunities, maintenance and administration of immovable property. Among them:

1. Law on Residential Properties;

2. Law On Administration of Residential Houses;

3. Cabinet Regulation No. 1013 - Procedures by which an Apartment Owner in a Residential Apartment House shall Pay for Services, which are Related to Usage of the Residential Property;

4. Cabinet Regulation No. 1014 - Regulations Regarding the Calculation of Payment for the Administration and Management of the Residential House;

5. Privatization of State and Local Government Residential Houses;

6. Associations and Foundations Law.

The above mentioned regulations and laws are mandatory for both the owners of the property, respectively, apartment owners and owners of the uninhabited areas, and the maintenance company, servicing the property including a particular number of apartments forming the residential building. The most ambiguous definition has been given to the delegated or authorized representatives of the intercommunity.

In the times of existence of the Soviet Union, the form of property was different, but still the "eldest of the house" or the supervisor of the house did exist and performed different tasks leading to successful and forehanded maintenance of the house. The surveillance mostly included arrangement of overall order, sometimes even cooperation with police (Militsiya) and other institutions. The present state system (democracy) and economic conditions (free market) reduce the rights of the delegated representatives, which is often 
neglected by persons performing these tasks for 10 years and longer. The habits of people often prevail over laws and regulations.

Currently, Section 16 "Competence of the Community of Apartment Owners" of the Law on Residential Properties states that "A community of apartment owners has the right to decide on any matter, which relates to the existing joint property share. The community of apartment owners, by entering into a relevant contract, may authorize another person to decide on a matter which is within the competence of the community, except the matters referred to in Paragraph Two of this Section". The exceptions are:

1) the alteration of the existing joint property share (increasing, decreasing);

2) the specification of the procedures for the use of the existing joint property share between apartment owners;

3) the establishment and revoking of the right of first refusal of apartment owners;

4) the granting and revoking of authorizations;

5) the specification of restrictions for the right of use;

6) the transferring for use of the existing joint property share;

7) the form of administration of the existing joint property share;

8) the assigning of individual or all administrative activities of the residential house to an administrator;

9) the procedures for the determination and payment of the administration expenditure of the residential house; and

10) other matters, which the community of apartment owners has specified as such that only fall within the competence of the community of apartment owners. [1]

Furthermore, Section 17 "Conditions for Decision-Making of a Community of Apartment Owners" of the same law states that "in order to take a decision on the matters referred to in Section 16, Paragraph Two, Clause 4 of this Law, it shall be necessary that apartment owners who vote "for" represent at least two-thirds of all apartment properties". [1] Often the requirement to gather such number of property owners becomes an insurmountable hurdle to making urgent decisions in the house. Passiveness, lack of interest and responsibility, stereotypes prevent owners of apartments from realizing the reality - the residential house belongs to the whole intercommunity, the only body able to make decisions and allow the maintenance company to perform works.

The growing number of persons renting the apartments also reduces the possibility to collect the indicated number of voices for or against an action or decision. The owners do not even consider the possibility to delegate someone to decide on the matters of the house. Detailed research shows that most people renting an apartment are young - older teens completing secondary school education, university and college students, and young adults at the age of 25-35. This category may be considered as one of the most active, capable and knowing to make correct decisions, willing to make the environment around better and enjoyable. The caution from the owners is not always well motivated. The maintenance company has no instrument to gather data, especially when the relationships between the owner and the renter are not regulated by a contract or any other financial document.

However, the main limitation has occurred due to privatization incompleteness characteristic of the most residential properties of the city of Riga. The law "Privatization of State and Local Government Residential Houses" in its Paragraph 51 describes many duties lying upon the owner of a privatized object, including "to participate in the joint administration and management of the multiapartment house by joining with the other owners of the house a society of apartment owners or by entering into a contract regarding administration and management of a joint property in conformity with the regulatory enactments in force". It is a duty both before and after - "a possessor of a state residential house or a local government has a duty to administer and manage the residential house until transfer of the administration rights of the residential house to a society of apartment owners or a person authorized by a mutual contract of apartment owners". [2]

The owners of the privatized objects often do not recognize all their responsibilities believing that all duties are bound to the state or city and their maintenance companies. Interviews, official meetings and individual conversations / consultations with the representatives of intercommunities, apartment owners, or persons renting residential spaces prove the ignorance concerning the basic principles built on weak knowledge of laws and regulations. Ignorantia juris non excusat (Latin for "ignorance of the law does not excuse") becomes a big hurdle that cannot be overcome by the state and municipal institutions willing to stimulate the development of the existing residential fund.

\section{THE MAIN TASKS AND PRIVILEGES AWARDED TO THE DELEGATED REPRESENTATIVES BY THE INTERCOMMUNITY}

The Law on Residential Properties keeps the right of the community of apartment owners or intercommunity to authorize another person to decide on the matters related to the residential building. However, the law provides no particular answer on the rights of such person. It only leaves some general questions in the competence of the full community opening a gap for the phantasy of the apartment owners.

Evidence has proven that most communities delegate the right to single-handedly decide on the matters related to the residential building consisting of separate apartments without mentioning particular tasks, rights or aims. The maintenance companies find it complicated to interpret such definition, being unable to deal with the person that has been authorized. Misunderstandings between both parties lead to tension, conflicts and postponed emergency and planned works.

A good example is related to the financial aspects of the common property. The apartment owners perform savings to complete a particular work. The delegated representative of the building believes that it is in his competence to decide on the type of work and the company performing the task without any meeting and common decision of intercommunity. The interpretation of the authorization text clearly lacks the right to decide on the collected money without any consultation with 
other apartment owners. The maintenance company is also unwilling to allow using the money knowing that at least one person in the intercommunity might be against and has a real chance to win in the court.

The analysis of the received minutes of the meetings of the apartment owners allows determining the most logical and useful formulations, which should become a chapter of the handbook of a professional authorized representative of a residential house. It is essentially important to delegate at least the following rights fully or partly to the representative:

1. The right to get acquainted and sign the deliveryacceptance deed of every work completed in the residential house (even emergency interferences);

2. The right to decide on spending definite money sums to cover the costs of a repair or maintenance work.

3. The right to decide on the executor of the repair or maintenance work, the type of contract signed.

4. The right to decide on the maintenance costs value, its increase or decrease.

5. The right to acquire additional data from the maintenance company - on the debtors, overall debt of the property, the debts of single privatized objects of the given residential house.

Otherwise, the delegated representative of the residential apartment building becomes a nominal deputy lacking any importance and having no rights to perform any task required by the building.

Even more often the authorized representatives of the intercommunity are ready and capable to inform other owners of the apartments on the renovation of the residential building, which is the main aim. Success would contribute to prolongation of the lifetime of a residential building. Still, the biggest drawback often is the lack of information and knowledge. The delegated persons are the most active individuals of the intercommunity, often acting harsh and without proper background.

At present, the evaluation draws a picture of an average authorized representative as a female, aged between 65 and 75 years, having a university degree or professional college education, with long working experience, but not related to immovable property or its maintenance, still capable to perform tasks due to natural activity, but lacking sufficient information. Traditionally, such persons are reliable, are trusted by the community, do not have any personal material interest, are engaged not willing to receive gratitude or any other kind of profit.

The task of the maintenance company is to educate more people to stimulate the election of numerous authorized representatives. The dynamics respectively depend on the activities performed by the maintenance company and global processes happening in the country. For example, seminars and educational programs form interest from the society, but migration inside the country and the whole union of the countries is followed by renting out apartments, which leads to definite complications in the functioning of an intercommunity conditioning a general lack of enthusiasm.
The rewarding the authorized representatives can both bring fast results, and thus increase the general number of such people, and can harm the project in long perspective. First of all, the authorized representatives in $99 \%$ of cases known to Ltd. "Rīgas namu pārvaldnieks" are the owners of flats in the apartment houses they represent. It is very rare that a neighbor is ready to take the work, and it occurs in cases, where the district consists of smaller apartment buildings (till 8-10 apartments per house). Similar or same architecture, common problems and requirements are an advantage to authorize a single person for 2 or more houses. Such trend does not harm the result. Actually, awarding or providing some material profit for such people might become an example of bad practice as the houses belong to intercommunities and proper maintenance is first of all their own primary interest. The responsibilities of the servicing company are secondary to the ones carried by the owners of apartments. On the other hand, the starting periods of work has to include some stimulation methods - material support (paper, printing, rooms for meetings, and use of the PC) and advice (legal, economic and technical consulting) might be sufficient for people willing to care for their immovable property. The position of Ltd. "Rìgas namu pārvaldnieks" in this contradiction is the following - to provide any possible support to the existing or potential representative to lead him/her to authorization according to the law of the Republic of Latvia and he/she finally has to sign a contract of cooperation, which is also a reference book for all intercommunity members.

Poor relations between the owners of apartments often become a problem. It is a high risk to offer any other material support to authorized representatives as it might lead to envy, suspicion on misuse of rights and undermine support of the maintenance company, municipality, state and other institutions. The last conclusion is very common due to personal economic problems of the apartment owners, the quality of living and other social-economic factors, personality characteristics and psychological aspects that are not going to be covered by the present article and its author.

\section{INTERNATIONAL EXPERIENCE AND LAW ON AUTHORIZED REPRESENTATIVES}

The presence of the delegated or authorized representative/s in multifamily apartment houses is not a very common practice in the European Union. Generally, the existence of such persons, as well as the right to choose such, is described in the housing policies of a country. However, the most important precondition is the ownership status of immovable property in any country observed. In case the apartment houses are or were owned by the state or municipality simultaneously with the right to privatize a single or several flats by the current tenant, the presence of an authorized representative becomes a very useful option. Such situation is very common for the former Soviet Union - respectively Eastern European countries.

It is interesting to observe the experience collected by countries, which are not members of the EU and have a worse ordered housing stock and corresponding policy. The 
questions regarding associations of intercommunities or owners of the real estate are not described in this chapter and deserve a more detailed research worth further publications.

For example, the Housing Code of the Republic of Belarus accepted in the year 2012, which underwent revision in January 2015, includes the term authorized representative of a multifamily apartment house in Clause 175 [5]. Respectively, Paragraph 1 of the mentioned clause gives the definition of the position that is different from the term agreed upon in the Law on Residential Properties of the Republic of Latvia. It says that in case the owners of the common property - the multifamily apartment house - were incapable to provide a common solution on the administration of the property then the local executives and authorities have to perform an open competition. According to the results of the competition, the authorized representative is elected using the procedure determined by the Council of Ministers [6]. An authorized representative is also awarded to a house in case the property is not correspondingly maintained - no refurbishments and servicing works are done even on demand.

The main difference to any other law or code mentioning the authorized representative, the Housing Code of the Republic of Belarus even declares the requirements for such person. He or she has to have secondary technical or higher education in the fields of technical sciences, finance or law. In addition, the candidate has to complete a special educational program on the maintenance of immovable properties.

According to the Latvian legislative acts described in the present article, the authorized representative is more a mediator between the owners of the property (even being one of the owners him- or herself) and the maintenance company. Rarely such a person becomes the provider of maintenance services - receiving a salary, performing operations with money and payments. Respectively, it is more a social activity than a regular paid work. Although there are no limits for a representative receiving according relevant education and registering as legal entity or self-employed person - the intercommunity might authorize him to perform maintenance.

The procedure determined by the Council of Ministers of the Republic of Belarus also states that the tasks of the representative are:

1. Supervision of the immovable property;

2. Organizing of the technical maintenance and repair works of the immovable property;

3. The provision of public services (water, sewage, waste treatment, etc.) to the owners of the immovable property. [5, 6]

He or she also has to control the payment discipline of the owners, control the current conditions of the property and provide the money further to companies ensuring public services. The authorized representative can be controlled by the authority, which has elected him, respectively local executives that organized the competition.
The Housing Code of the Russian Federation has more in common with Law on Residential Properties of the Republic of Latvia. Clause 44 of the Code declares the rights of the intercommunity to provide different forms of authorization to a delegated or authorized representative. To receive the warrant, a person or persons have to gain the support of the $2 / 3$ of all owners of the immovable property or more than $67 \%$ [7]. The intercommunity keeps the right to recall any kind of provided rights. The Code and any other acts do not provide information on the required background or payment possibilities. These questions are still within the competence of the intercommunity.

The possibility to elect a representative has almost the same justification - to control the performance of the maintenance company, to provide sufficient information to the intercommunity and to control the conditions of the property. The reasons are also very common - even armed with very detailed legislative acts indecent private maintenance companies are capable to cheat on bills, costs of refurbishments and repairing works, and perform other illegal deeds, which is impossible for municipal maintenance companies.

There is no doubt that the sphere of immovable property maintenance is a very weak link in any country that has recently (in terms of the overall history of humanity) switched to democracy from other forms of governance, and where the immovable property sector still has ownership and servicing problems. Official and unofficial statistical researches state that this sector of the national economy has high risks of corruption. The introduction of the term "authorized representative" almost in any country has the aim to install an additional controlling body to make the processes around a multifamily apartment house clearer and more transparent.

\section{THE Housing StOCK OF THE CITY OF RIGA}

The housing stock of Riga should be observed along with the statistical data of the whole country. The Ministry of Economics of the Republic of Latvia has recently published the report, providing information on the current situation in the country according to the project "Building Renovation Long-term Strategy 2014-2020". Table 1 sums up the amount and area of the energy consuming residential houses in Latvia. $[8,9]$

The same report also advises to classify the housing stock by age. The information is crucial with regard to the lifetime of every building - information important for the apartment owners and any maintenance company.

The construction period or even particular date (normally known to the owners or determinable by archive or other sources) is the source of general information on the building, including some hints on construction materials, overall quality and primary purpose. The report also provides the data on thermal characteristics of the buildings in accordance with their age. 
TABLE 1.

THE AMOUNT AND AREA OF ENERGY CONSUMING RESIDENTIAL HOUSES [9]

\begin{tabular}{|c|c|c|}
\hline Main usage aim & $\begin{array}{l}\text { Amount, } \\
\text { thousands }\end{array}$ & $\begin{array}{c}\text { Area, } \\
\text { million } \mathrm{m}^{2}\end{array}$ \\
\hline \multicolumn{3}{|c|}{ Residential houses } \\
\hline $\begin{array}{l}\text { Single family house with one } \\
\text { apartment }\end{array}$ & 300.7 & 33.9 \\
\hline $\begin{array}{l}\text { Terrace house with two } \\
\text { apartments }\end{array}$ & 12.4 & 2.5 \\
\hline $\begin{array}{l}\text { Multifamily house with three and } \\
\text { more apartments }\end{array}$ & 38.6 & 50.4 \\
\hline Different social groups & 0.7 & 0.1 \\
\hline Altogether & 352.4 & 86.9 \\
\hline
\end{tabular}

The major group of buildings forming the centers of the most cities of Latvia has been constructed before 1940. In urban territories the main material has been stone with single wooden elements, sometimes including the ceilings. Among them are also completely wooden houses, which comprise 2-3 floors and have the strictest requirements of maintenance. [9]

The next observed period is from 1941 up to 1960 . The determining feature is quality as modern bricks were used, but the design has excessive reserves on any possible parameter. [9]

The period 1961-1979 became the beginning of the age of typical buildings, when a single design has been multiplied not only in a city, but has been widely used around the country or union. Standard internal layouts were also called series. Most of them were developed and built particularly during this period. The most well-known series are 316 and 318 (also known as Khrushchev'kas), 464, 467, 103 and 104. Later 602 series was introduced and applied almost till 1990's. The most characteristic material was concrete and its modifications, ensuring fast, reliable and massive constructing. [9]

Eleven years from 1980 up to 1991 were determined by USSR construction standard "Thermal engineering of enveloping elements". Advanced modifications of concrete allowed introducing the series 119 , which was adopted later as well. [9]

The Latvian Ministry of Architecture and Construction issued the order No. 68 of September 12, 1991, revising the requirements and standards of the enveloping elements of constructions. In 1992-2002, the market received an additional impulse due to a wide variety of unique projects based on most modern materials. [9]

In 2003 the local standard LBN 002-2001 was introduced and became the foundation defining thermal engineering principles of enveloping elements. The variety of projects continued to grow, while the next period might be determined from the year 2014 because of the new revised Construction Law. [9]

The lifetime of every category varies; the oldest ones might be the most solid ones, capable to carry the maximal load during the longest period. The houses constructed during the past 50 years need a detailed analysis including expertizes and onsite inspections, calculations of thermal performance and other crucial parameters, energy audits, and finally - renovation. According to Annex 1 of Cabinet Regulation No 907 of $28^{\text {th }}$ September, 2010, all buildings can be divided in solidity groups in accordance with the used materials and other factors. Table 2 is an excerpt from the annex; it omits first 3 groups with an average lifetime above 100 years. Such buildings are a minority among the stock maintained by the Ltd. "Rīgas namu pārvaldnieks", they require a specific approach in accordance with special conditions and the treatment is often related to sustaining the historical design of the façade and other elements.

The series or as they are named in the regulations - batches - performed from different modifications of concrete are the group of risk being the most massive part of the housing stock in the city of Riga.

TABLE 2.

ClassificATION OF RESIDENTIAL HOUSES INTO SOLIDITY GROUPS ACCORDING TO THE MATERIALS USED, CONSTRUCTIONS AND AVERAGE LIFETIME [3]

\begin{tabular}{|c|c|c|c|c|c|c|}
\hline \multicolumn{2}{|c|}{$\begin{array}{l}\text { Solidity } \\
\text { group }\end{array}$} & $\begin{array}{c}\text { Foundation } \\
\text { construction, } \\
\text { material }\end{array}$ & $\begin{array}{c}\text { Load-bearing } \\
\text { walls - } \\
\text { frameless } \\
\text { construction- } \\
\text { material } \\
\text { load-bearing } \\
\text { frame, } \\
\text { construction } \\
\text { material }\end{array}$ & $\begin{array}{c}\text { Roof } \\
\text { construction, } \\
\text { material }\end{array}$ & $\begin{array}{l}\text { Average } \\
\text { lifetime } \\
\text { of the } \\
\text { residenti } \\
\text { al house } \\
\text { in years }\end{array}$ & Notes \\
\hline IV & $\begin{array}{l}\text { Mass } \\
\text { produ } \\
\text { ction } \\
\text { buildi } \\
\text { ngs }\end{array}$ & $\begin{array}{l}\text { Monolithic } \\
\text { concrete and } \\
\text { reinforced } \\
\text { concrete, } \\
\text { including on } \\
\text { a plate, } \\
\text { premanufactu } \\
\text { red element } \\
\text { or pile } \\
\text { foundation } \\
\end{array}$ & $\begin{array}{l}\text { Stone (brick) } \\
\text { or large panel }\end{array}$ & $\begin{array}{l}\text { Reinforced } \\
\text { concrete, } \\
\text { premanufactu } \\
\text { red elements }\end{array}$ & 70 & $\begin{array}{c}\text { Batches } \\
1-316 \\
1-318 \\
119\end{array}$ \\
\hline $\mathrm{V}$ & $\begin{array}{l}\text { Mass } \\
\text { produ } \\
\text { ction } \\
\text { buildi } \\
\text { ngs }\end{array}$ & $\begin{array}{l}\text { Monolithic } \\
\text { concrete and } \\
\text { reinforced } \\
\text { concrete, } \\
\text { including on } \\
\text { a plate, } \\
\text { premanufactu } \\
\text { red element } \\
\text { or pile } \\
\text { foundation }\end{array}$ & $\begin{array}{l}\text { Panel and } \\
\text { large panel }\end{array}$ & $\begin{array}{l}\text { Reinforced } \\
\text { concrete, } \\
\text { premanufactu } \\
\text { red elements }\end{array}$ & 60 & $\begin{array}{c}\text { Batches } \\
103 ; \\
104 ; \\
1-464 ; \\
1-467 \mathrm{~A} ; \\
1-602 ; \\
602 \mathrm{P}\end{array}$ \\
\hline VI & $\begin{array}{l}\text { Low- } \\
\text { rise } \\
\text { buildi } \\
\text { ngs }\end{array}$ & $\begin{array}{l}\text { Stone } \\
\text { concrete, } \\
\text { strip concrete }\end{array}$ & $\begin{array}{l}\text { Brick wall or } \\
\text { timber } \\
\text { framework } \\
\text { building and } \\
\text { log buildings }\end{array}$ & $\begin{array}{l}\text { Timber } \\
\text { beam, } \\
\text { reinforced } \\
\text { concrete } \\
\text { premanufactu } \\
\text { red elements, } \\
\text { mixed } \\
\text { construction }\end{array}$ & 50 & $\begin{array}{l}\text { Batches } \\
\text { M3; } \\
\text { M4 }\end{array}$ \\
\hline
\end{tabular}

Series or batches have to be under constant supervision not to miss any alterations in constructions as many similar houses have been constructed by different builders (professionals, military service, student construction crews, etc.) or on different ground (many districts used to be swamps with numerous currently drained small rivers and underground wells).

\section{THE ANALYSES OF THE CURRENT SITUATION AND THE LINK WITH ENERGY EFFICIENCY}

The overall number of the buildings maintained by Ltd. "Rīgas namu pārvaldnieks" is around 4,300. The final aim is to stimulate the election of authorized representatives in all 
serviced houses and to permanently support their work. Having hundreds of thousands of clients complicates direct communication with the house. For example, similar questions or offers might be received from apartment owners living in the same residential house. The task of the representatives of the intercommunity might become collection, analysis and centralized submission of the applications, thus reducing the necessity to communicate with all clients, limiting the number of contact persons to the number of the maintained houses. Such structure is shown in Fig. 1.

Currently, the number of active authorized representatives is limited to 150 . That number has been obtained analyzing the activity during the past 6 months: responses to the newsletters, meetings in the districts, participation in centralized study meetings, regular correspondence and phone calls were the main evaluated aspects that allowed determining the most active part of the authorized representatives performing their everyday tasks and establishing constant communication with the maintenance company.

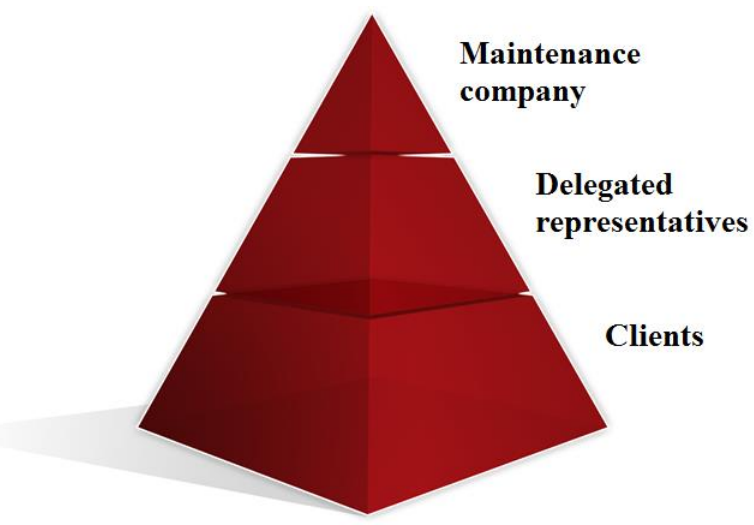

Fig. 1. Pyramid structure of the favorable contact scheme.

Although the analyzed number of authorized representatives, activists and association representatives is based on a humble number from the statistical point of view, it is sufficient remembering that the final number currently is just above 4,000.

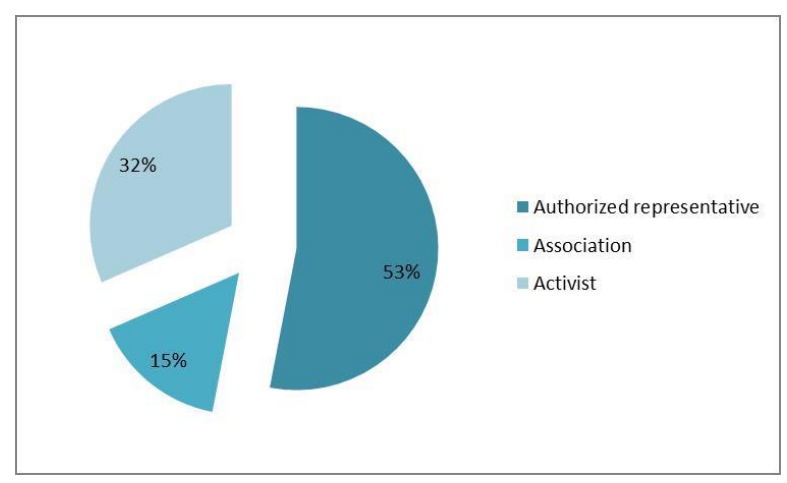

Fig. 2. The distribution of the "roles" among the active representatives.

Fig. 2 presents relative distribution of the so-called "roles" of the representatives of the residential houses. There are still many activists that voluntarily perform the same tasks as the fully and legislatively correctly elected authorized representatives or established associations. The tasks lying upon the maintenance company is to stimulate the making of the decision according to the form and law, as many activists face not only support among their neighbors, but also active aggression and doubts. The main reasons for doubts are related to the financial aspects - often it is stated that the authorized representative receives money from the maintenance company, performs venality completing renovation and refurbishment works, which as a matter of fact is not true and has never been true. Such attitude prevents from starting such global projects as energy audit that normally forestalls the general renovation of the residential building.

The local legislative acts are missing the definitions of the competences of the authorized representatives - the responsibilities and tasks of the person are unclear for the authorized person and the intercommunity. Such drawback often leads to misunderstandings - the maintenance company cannot perform a task or decision of the owners of the apartments of the residential building as it is not in its scope of responsibility. Often the decisions exceed the abilities and rights of the intercommunity of a house that has not finished the privatization procedure.

Constant work with the clients, especially existing and potential authorized representatives has led to actual and determined results. Apart from the aim to reach a higher level of maintenance and self-governance of the residential buildings, it is important to prolong the lifetime of the buildings. The first step towards the renovation is to perform energy audit.

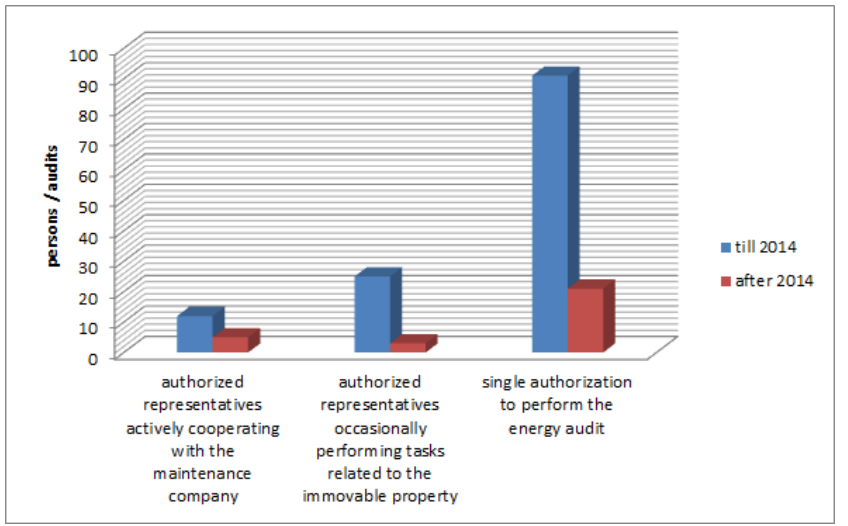

Fig. 3. Energy audits performed by authorized representatives.

The overall number of energy audits completed during the past two years is 157 - even more than the number of active authorized representatives. Deeper analysis of the numbers showed that a regular case is to provide a person with the right to order and control the energy audit and further renovation without any other authorization tasks. The reason might be the attempt to minimize the impact of the single person on the entire processes and works in and around the house. Reduction of the rights minimizes the risks of the intercommunity, ensures stability in control and the transparency of deeds. 
It is important to emphasize the fact that energy audit in Latvia is completed by certified experts, who acquired relevant education and the right to perform the task technically. Such persons are registered by the Ministry of Economics of the Republic of Latvia [10]. The list is open to viewers and used by the real estate maintenance companies and the Riga Municipal Agency "Riga Energy Agency" [11], which often acts as a mediator in the orders for energy audits, especially in case the municipality offers co-financing of the task [4].

Only around $29 \%$ of audits were initiated by persons performing other tasks related to the common property. The only conclusions that can be made without going in detail and researching every case can be the fact that only this number of representatives gained trust form the intercommunity. It can be due to personal qualities of the person, but mostly because of the knowledge and professionalism of the person. For details please see Fig. 3.

The result can be scaled to define the current image - more than a half of the existing representatives act intuitively, lacking specific knowledge and experience. Particularly this shows the relation between the prolongation of lifespan of the residential stock and energy efficiency with the educational work of Ltd. "Rīgas namu pārvaldnieks".

Although energy auditing and minor repairs of the immovable property bring the city closer to the prolongation of the lifespan of the buildings, the initial number of completed full renovations is very humble -2 during the past 3 years.

Still, the reason is not hidden in education or the everyday work of the maintenance company, but concentrates around the financial risks to be concerned. The presence of a single debtor in the intercommunity becomes the burden for other fair payers. The savings done by the intercommunity for repair works do not grow as fast as they would in case all property owners would make the same regular contribution. The load of the renovation is carried for several decades. In the present social and demographic context, the possibility that an owner might sell or rent his/her property, emigrate for a short or long term is very high.

\section{CONCLUSIONS}

The combination of the interdisciplinary - scientific and legislative - research allowed drawing several conclusions that might help solving existing problems and set new goals for the maintenance company, intercommunities, owners of immovable property and state lawmaking institutions in the fields of energy efficiency, renovation, financing of the projects and the authorization of representatives of intercommunities:

1. The correlation between the existing number of the authorized representatives and performed energy audits is rather poor and can be neglected, as other factors such as financial and social instability have greater impact on the decision and minimization of risks carried by the intercommunity owing an object of immovable property.
2. Proper education of authorized representatives increases the feeling of responsibility of the whole intercommunity. A higher level of knowledge transferred by the maintenance company or other reliable source to the representative forms a flow of information similar to a pyramid structure.

3. The provision of tools to the authorized representatives simplifies the work of the maintenance company expertizes, inspections, offers of refurbishment works are made in cooperation with the intercommunity or a delegated person. It saves time, resources and brings a faster result.

4. The initial aim of any intercommunity is to ensure long lasting comfort and safety, or generally the stability of the owned residential house. Any works completed or initiated have to improve the current conditions. One of possible instruments offered to the delegated representatives and intercommunities is energy audit with further renovation.

5. Financial instruments proposed by the state, municipality and the European Union are one of the main factors to stimulate interest and completion of energy audits. Existing co-financing program of the Municipality of Riga is a good example, as it provides $80 \%$ of the costs of the energy audit procedure. [9]

6. The author and Ltd. "Rīgas namu pārvaldnieks" are going to continue the research and obtain new data according to the current situation and its conditions. The overall plan is to provide educational programs to the authorized representatives and afterwards evaluate the success of their everyday work.

\section{REFERENCES}

[1] LR Law on Residential Properties (Latvian version - "Latvijas Vēstnesis", 183 (4375), 17.11.2010.)

[2] LR law on Privatization of State and Local Government Residential Houses (Latvian version - "Latvijas Vēstnesis", 103 (386), 11.07.1995., "Zinotājs", 16, 24.08.1995.).

[3] Cabinet of Ministers Regulation Nr. 907. (Ministru kabineta noteikumi Nr. 907 „Noteikumi par dz̄̄vojamās mājas apsekošanu, tehnisko apkopi, kārtējo remontu un energoefektivitātes minimālajām prasībām”).

[4] The Binding Regulation of the Riga City Council Nr. 47 (Rịgas domes saistošie noteikumi Nr.47 (Rīgā 2013.gada 24.septembrī) „Par kārtību, kādā Rīgas pilsētas pašvaldība sniedz palīdzību energoefektivitātes pasākumu veikšanai dz̄ivojamā mājā").

[5] The Housing Code of the Republic of Belarus (Belorussian version in Russian - ЖИЛИЩНЫЙ КОДЕКС РЕСПУБЛИКИ БЕЛАРУСЬ, 28 августа 2012 г. № 428-3).

[6] Decree of the Council Of Ministers of the Republic of Belarus (Belorussian version in Russian - Постановление Совета Министров Республики Беларусь от 30 марта 2005 года, № 342 Об утверждении положений об уполномоченном лице по управлению недвижимым имуществом совместного домовладения и о конкурсе на право заключения договоров на техническое обслуживание и (или) ремонт жилищного фонда).

[7] The Housing Code of Russian Federation ("ЖИЛИЩНЫЙ КОДЕКС РОССИЙСКОЙ ФЕДЕРАЦИИ" (ЖК РФ) от 29.12.2004 N 188-ФЗ).

[8] Housing Conditions $<$ http://epp.eurostat.ec.europa.eu/statistics_explained/index.php/Housing _conditions> [December 2013]

[9] "The Renovation Strategy", the Ministry of Economics of the Republic of Latvia (Ekonomikas Ministrija. "Ēku renovācijas ilgtermiṇa stratēǵija 2014. 2020.gadam") 
Proceedings of REHVA Annual Conference 2015 "Advanced HVAC and Natural Gas Technologies"

Riga, Latvia, May 6 - 9, 2015

<www.mk.gov.lv/doc/2014_03/EMZinoPielik2_170314_VEERP.253.do c>, May 25, 2014

[10] The Ministry of Economics of the Republic of Latvia - The Register of Certified Energy Auditors <https://www.em.gov.lv/files/attachments/ENERGOAUDITORI_PUBL ISKAIS.pdf>

[11] Article by Riga Municipal Agency "Riga Energy Agency" on the renovation project completed in Riga by the Ltd. "Rīgas namu pārvaldnieks" (Atskats uz ,atvērto durvju dienas” pasākumu pie daudzdzīvokḷu dzīvojamās ēkas Rīgā, Finiera ielā 15) < http://www.rea.riga.lv/component/content/article?id=863>, February 26, 2015. 